Vol. XXIII, No. 2

\title{
SANDHILL CRANE STUDIES ON BANKS ISLAND, NORTHWEST TERRITORIES
}

\author{
by Lawrence H. Walkinshaw, Battle Creek, Michigan \\ (Illustrations by the author)
}

Bird records from Banks Island, Northwest Territories, Canada, published by Manning et al. (1956) included information on the Lesser Sandhill Crane (Grus canadensis canadensis). Since the island has one of the northernmost breeding crane populations in the world, I selected it as a study area. I was there from June 9 until July 1, 1964 .

Although Sachs Harbour was the center for my work, two camping trips were made away from there. On June 12 and 13 I was at Fish Lakes, about 20 miles east of Sachs Harbour, and on June 15-27 camped on the bank of an unnamed stream, which I called "Sand Creek," about six miles east of Sachs Harbour. On June 30 I hiked north to the Kellett River and twice, on June 11 and 28, I walked westward to the Cape Kellett region.

Except for the southern slopes of the ridges and hills, much of Banks
Island was still snow covered when I arrived. Some of the southern edge, the slope down to Amundsen Gulf, was nearly free from snow and on warmer days it was quite muddy in places. North of the ridge there was still much snow on July 1 and most of the larger lakes and the Beaufort Sea were still frozen with up to five to seven feet of ice.

Both of my camps were on snowless ridges, well drained and high above surrounding lakes and ocean. During the 22 days I was there I estimated I walked 207 miles and covered 60 miles by dog sled. During this time 32 species of birds were observed and 42 nests of 13 species were found.

At the Sachs Harbour weather station, the average June temperature recorded was $30.3^{\circ} \mathrm{F}$. with a low of $19.8^{\circ}$ on June 9 and a high of $42.4^{\circ}$ on June 25 . There were only 16 days in June with temperatures above

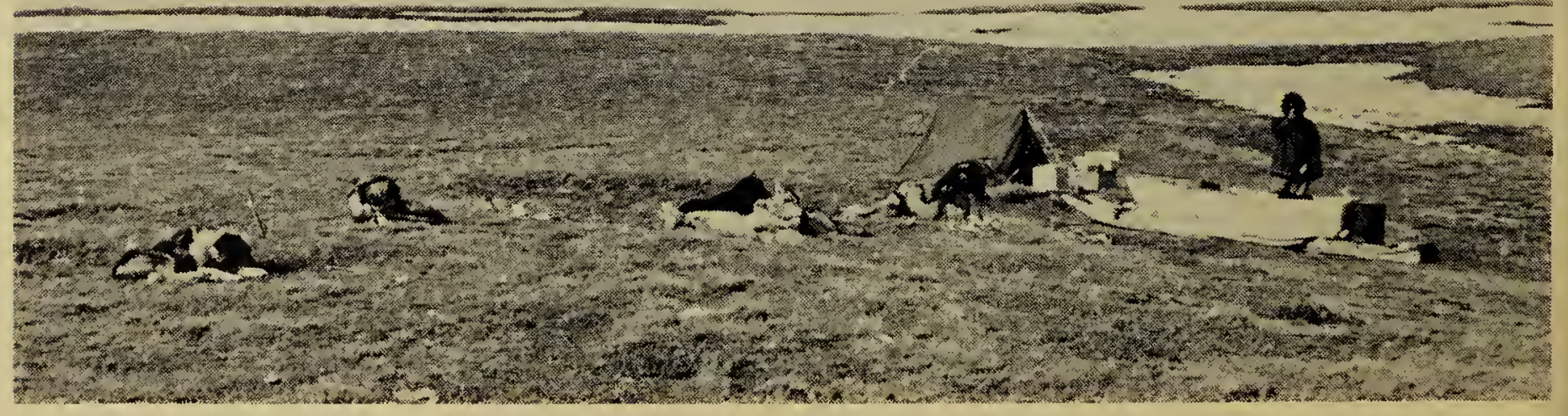

Fish Lake Camp, Banks Island, June 12, 1964 


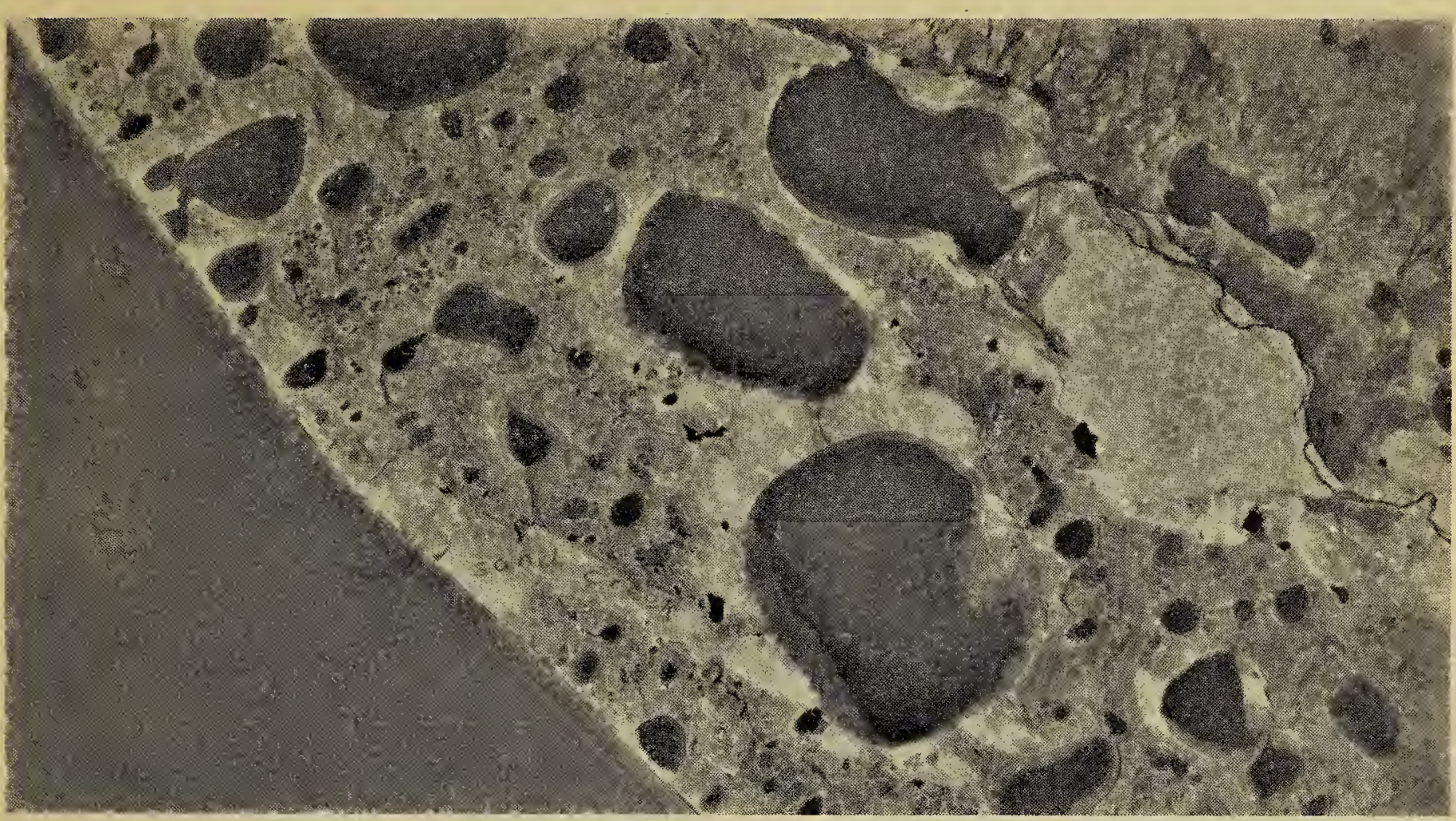

Canada Department of Mines and Technical Surveys Aerial photo of study area southeast of Sachs Harbour, Banks Island

freezing while there were 22 days with temperatures below $35^{\circ} \mathrm{F}$. George Clouvidakis from the Federal Department of Transport headquarters was in the field for a short time every afternoon. He observed the first cranes at Sachs Harbour on May 15. The temperature for May 14 was, high, $27^{\circ}$ and low, $17^{\circ} \mathrm{F}$. and for May 15 , $17^{\circ}$ and $-1^{\circ} \mathrm{F}$.

When the cranes arrived, they landed on the partially open south slope of the extensive ridge along the southern edge of Banks Island. Here they fed on the bare tundra. South

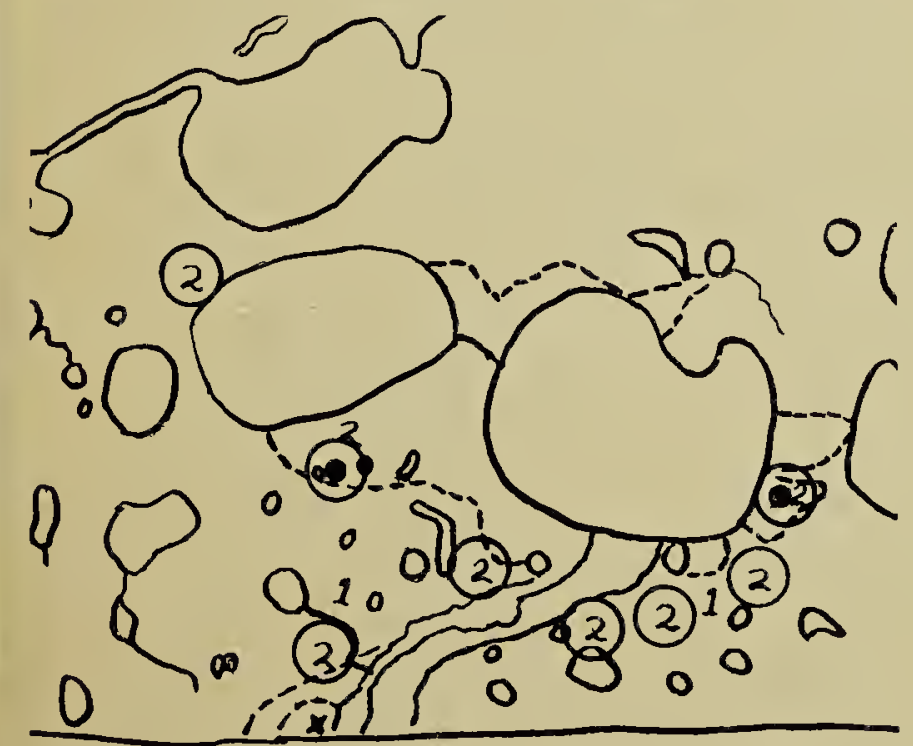

Sketch map of study area. Circles with numbers inside show territories of pairs. The numeral 1 indicates a lone non-breeder. Nests are black dots. $\mathrm{X}$ - my camp. of the Sachs River at both Fish Lakes and "Sand Creek" were extensive sand dunes. These lost their snow earlier than most other sites and temporary small ponds were scattered amongst the dunes. These supplied water for cranes and other birds. They also offered crane nesting sites.

On June 11, I observed groups of one, three, one and two cranes between Sachs Harbour and Mary Sachs; on June 14 groups of two, one, two and three. The latter group was flying northeast about $100 \mathrm{~m}$. above ground and disappeared into the snowy region along the Kellett River. At Fish Lakes, June 12 and 13, I found two crane nests and at "Sand Creek," two more. I found only the two pairs at Fish Lakes and eight resident pairs at "Sand Creek."

Although I found all four crane nests by June 19 there were only five days prior to June 16 (May 20, 31, June $1,14,15$ ) when temperatures went above $32^{\circ} \mathrm{F}$.

\section{Crane Territorial Behaviour}

The cranes at Sachs Harbour showed no signs of territorial behaviour. This apparently was a stopping place as they flew farther northward. Neither pair at Fish Lakes showed signs of territorial defense but then both pairs were already on eggs, at which time they are less aggresisive. At "Sand Creek" there was much defence of ter- 
ritory. Here the eight pairs occupied an area of about 18 square miles, or 11,520 acres $(4,661$ hectares $)$. All orane territories contained some tundra and all had some sand dunes except one. Much of the 18 square miles was unsuitable to cranes so that only about one-half of the area was directly under crane control. Each pair averaged about 720 acres $(291.3$ hectares). Only two of the eight pairs were on eggs. These birds were rather quiet and inconspicuous. The remaining pairs called regularly and flew about a great deal both day and night. They showed much concern over territorial boundaries. If any crane or cranes landed on or adjacent to their territory, they immediately chased them far away. Sometimes both birds, sometimes only one chased the intruder away. Since the six pairs were still not on eggs by June 27, I felt that they were not going to nest in 1964 because winter begins by late August or early September on Banks Island.

The nesting pairs had feeding territories from one-half to one mile from the nest site.

\section{Crane Nests}

NEST 1. Between Fish Lake and Sachs River, June 13, 1964. Two eggs.

As I walked across the tundra, suddenly a crouched crane with lowered head was running with outspread wings only 40 feet from me. The bird ran between this point and one several hundred feet away and when I left trotted parallel to me for a short distance. Only once did she call a shrill "Karoooo - karoooo - karoooo." There were many Long-tailed Jaegers (Stercorarius longicaudus) all through the surrounding tundra. As I left they began flying back toward the nest. The crane immediately turned and trotted back and three minutes after I had left it, she was standing over, and soon settled down onto the nest.

The nest was merely a few pieces of creeping willow torn from nearby plants. It was built on top of a mound which, though small, was still the highest tundra mound in the vicinity, and not very far from the shore of a small tundra lake. The nest depression was $37 \mathrm{~cm}$ across, slightly depressed for the eggs. The eggs measured $86 \times 55.5$ and $89.2 \times 52.1 \mathrm{~mm}$, were buffy colored and marked spar- ingly with shades of brown, some lavender, and black.

NEST 2. Near the Sachs River north of Fish Lake. June 13, 1964. Two eggs.

A crane flew only a few hundred feet from me, from the top of a high dune, as I walked through an extensive dune area. It flew directly across the Sachs River where it paced silently back and forth. When I departed it uttered a single bugle and as I disappeared, both birds flew, calling, back toward the nest. There were no signs of jaegers, foxes, or gulls in this area.

There was no snow in the vicinity. A few plants had been pulled up and tossed into a depression on top of the dune. The depression measured $40 \times 43$ $\mathrm{cm}$ across. The two eggs lay at right angles to each other and measured $82.4 \times 54.1$ and $82.7 \times 56.7 \mathrm{~mm}$, were ovate-shaped and marked much like Sora eggs.

NEST 3. Six miles southeast of Sachs Harbour, two to three miles north of "Sand Creek" camp. June 16, 1964. Two eggs.

The parent flushed at 500 feet as I stalked in a large dune area. She then paced silently a few hundred feet away as I studied the nest and when I left the area she uttered a series of bugles. Her mate was not seen. On June 21-22 I watched this nest from three-quarters of a mile aw ay throughout the night. It was clear but bitter cold. The bird that was on the nest at 8:00 p.m. was still there at $7: 32$ a.m. the following morning. The second bird flew directly from its feeding area to the top of the dune and they changed places calling in unison. The setting bird flew from the nest directly out onto the tundra about threequarters of a mile away. During the night the setting bird rose at $8: 15$ p.m. for one minute and at 10:55 p.m. for two and one-half minutes to work with the eggs. Otherwise she did not rise throughout the night.

The nest measured $43 \mathrm{~cm}$ across, was built of pieces of dead dune grass stalks, and was in a slight sandy depression on top of the highest dune. The eggs measured $86.0 \times 57.1$ and $86.9 \times 55.2 \mathrm{~mm}$ and weighed 120.0 and $126.2 \mathrm{~g}$. One was much darker than the other and much more heavily spotted. Besides the two 1964 eggs 
there were remains, indicating that they had hatched, of two other eggs apparently from the 1963 season.

NEST 4. About eight miles southeast of Sachs Harbour, east of "Sand Creek." June 19, 1964. Two eggs.

I sat on a prominent dune and scanned with binoculars the tops of the visible dunes, soon spotting a setting crane on top of a distant dune. This dune, about the same as the others, was about four m. high, six to seven $m$. in diameter and surrounded by many similar dunes. The parent did not flush until I was 100 $m$. from her, then flew to the top of another dune where her mate joined her and both called periodically while I was there. The nest was better built than the others, with about one or two inches of dune grass piled into a depression on the extreme top of the dune. The nest measured $50 \times 52$ $\mathrm{cm}$ across and was depressed about $3 \mathrm{~cm}$. The eggs measured $86.7 \times 53.4$ and $90.0 \times 56.1 \mathrm{~mm}$ and were not as heavily spotted as the others. On the edge of this nest there were also remains of egg shells from a previous year.

Manning et al. (1956) described a Sandhill Crane nest on Banks Island, showing an illustration of it also, built on top of a sand mound along the Sachs River, and another nest near Sachs Harbour. They found a downy young with its parents, July 18, 1953, near the Kellett River and 16 pairs of cranes in the valley of the Thomsen and Muskox rivers which were apparently breeding July 14 and 15,1953 . The largest number of cranes in a group observed by me was three.

The two nests reported by Manning et al. (1956) were found June 21, 1952 and June 15, 1953. The four $I$ found, June 13,13, 16 and 19, 1964 and the two they found, all contained two eggs.

Crane nests that I found at Chevak and Johnson River, Alaska, during June 1946 were built chiefly on dirt mounds. A Sandhill Crane nest that I found June 4, 1964, near Ft. Smith, Wood Buffalo Park, Canada, had two downy young, one just hatched. This nest was a large mound of piled up sedges (Carex sp.), rushes (Scirpus validus), and grasses, $62 \times 69 \mathrm{~cm}$ across, $8 \mathrm{~cm}$ tall and placed in 30.5 om of standing water. It was surrounded by dead, hip-high rushes, sedges and grasses. The Alaska and Banks Island nests had very little vegetation around them. Nests found by Baker and me (1946) in central Alberta in 1942 were merely a few

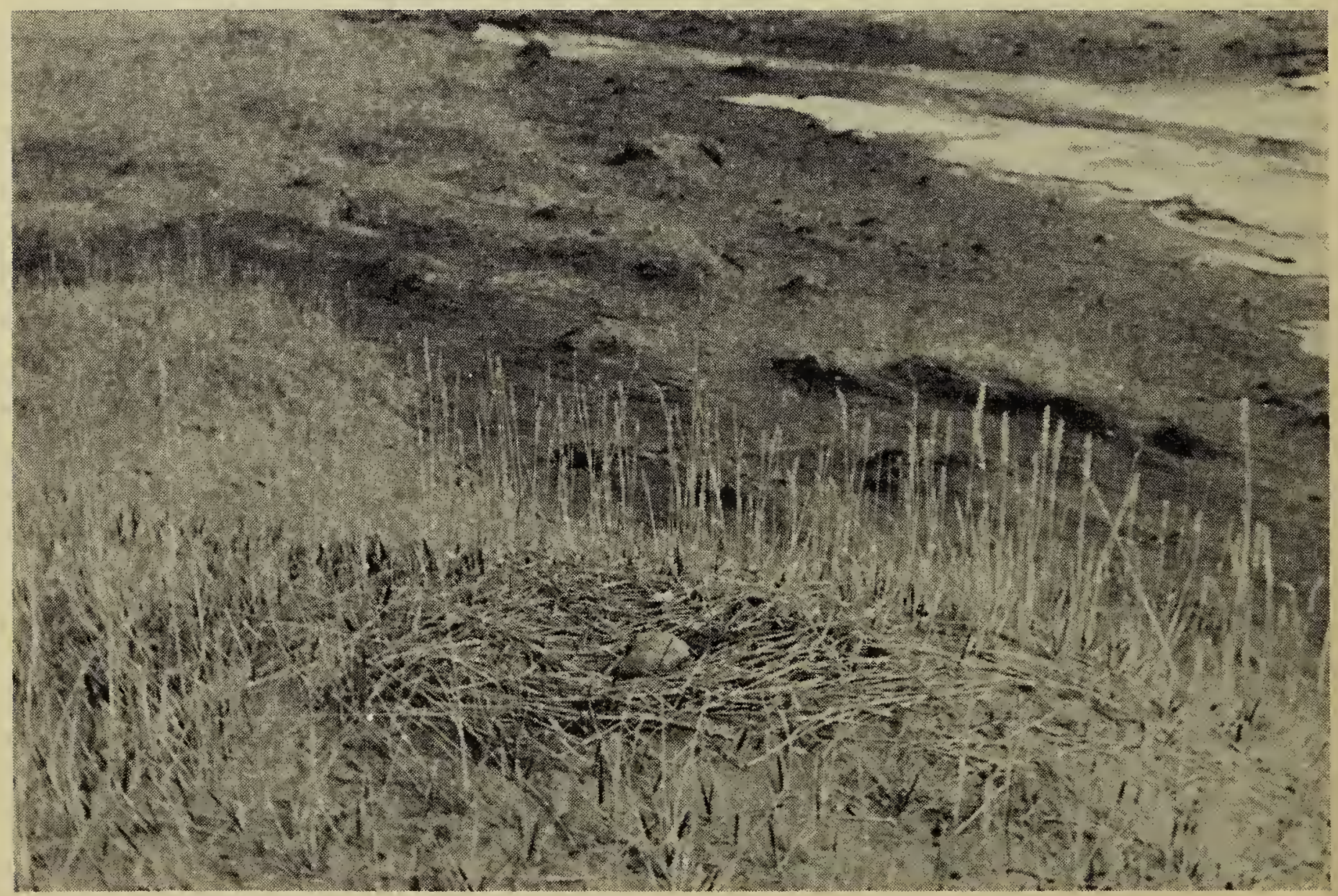

Sandhill Crane nest, 10 miles east of Sachs Harbour, June 19, 1964 
pieces of grass placed on dry dwarf birch ridges.

The average and extreme measurements for the eight Banks Island crane eggs was $86.23 \quad(82.4-90.0) \mathrm{x}$ 54.9 (52.1-57.1) $\mathrm{mm}$ and two, in weight, $123.1 \mathrm{~g}$. The seven Alaska eggs averaged $91.6(86.5-95.5) \times 55.1$ (53.1-56.5) $\mathrm{mm}$ and weighed 137.9 (118.3-155.0) g., indicating that Banks Island birds might be smaller. Those at Fawcett, Alberta, May 22 and 23, 1942 , measured $96.8(95.5-99.0) \times 60.8$ (60-62) $\mathrm{mm}$ and weighed 173.0 (159.1$190.0) \mathrm{g}$.

\section{Other Crane Notes}

An adult male crane was taken June 14, 1964 at Sachs, Harbour. The wing (chord) measured $469 \mathrm{~mm}$; tarsus, $178 \mathrm{~mm}$; culmen, $82 \mathrm{~mm}$; bare tibia, $64 \mathrm{~mm}$; middle toe, $85 \mathrm{~mm}$; and it weighed $2.96 \mathrm{~kg}$. The stomach contained fine pieces of gravel and a small amount of vegetable matter amongst which some small insects could have been mixed. The remains of another bird were found at Sachs Harbour on June 16. Its culmen measured $99 \mathrm{~mm}$. Four tarsi found at Fish Lakes, June 12, measured 180, 180, 180 and $178 \mathrm{~mm}$.

Crane tracks were found in many places. The average measured $120 \mathrm{~cm}$. across, about $90 \mathrm{~cm}$. long and the average length of a step for normal walking was $39(34-43) \mathrm{cm}$. One set measured at Ft. Smith, Wood Buffalo Park, N.W.T., Canada, measured 90 $\mathrm{mm}$ long and $104 \mathrm{~mm}$ across. In comparison it was roted that steps taken by cranes in southern Michigan were longer, averaging $43.5(41-47) \mathrm{cm}$.

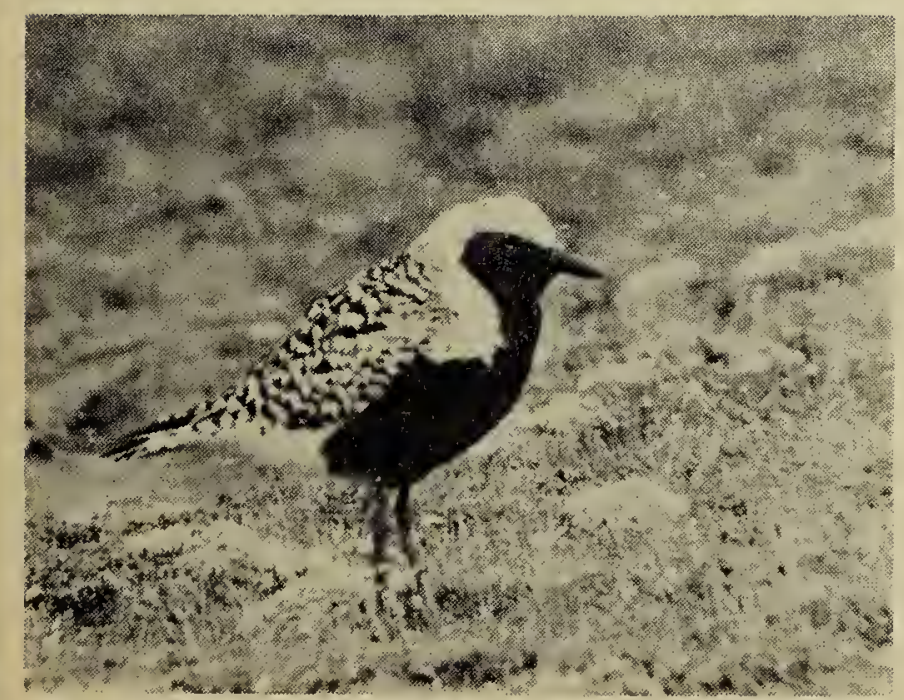

Black-bellied Plover, Banks Island, June 23, 1964
Data on Other Nesting Birds

Whistling Swan (Olor columbianus) 2 nests: June 17, 2 eggs; June 19, female on eggs.

Brant (Branta bernicla): Probable nest with broken eggs.

Lesser Snow Goose (Chen caerulescens hyperborea) 1: June 23, 7 eggs.

King Eider (Somateria spectabilis) 3: June 25, 4 eggs; June 29, 4 and 2 eggs.

Semipalmated Plover (Charadrius semipalmatus) 1: June 13, 4 egrss.

Black-bellied Plover (Squatarola squatarola) 4: June 22, 4 eggs; June 25, 4 eggs; June 25, 4 eggs; July 1, 2 eggs.

Ruddy Turnstone (Arenaria interpres) 1: June 15, 4 eggs.

Baird's Sandpiper (Erolia bairdii) 2: June 22, 2 eggs; June 30, 3 hatching eggs and 1 infertile egg.

Semipalmated Sandpiper (Ereunetes pusillus) 1: June 19, 4 eggss.

Hoyt's Horned Lark (Eremophila alpestris hoyti) 6: June 12,5 eggs; June 19, 5 eggs; June 22, 4 eggs; June 25, 5 eggs; June 28, 3 young; and June 29, 4 young.

Lapland Longspur (Calcarius lapponicus) 15: Six nests were found June 12-13 at Fish Lakes, four with six eggs each, two under construction. Four nests were found at Sachs Harbour, June 14, 6 eggis: June 15, 7 eggs; June 28, 5 eggs; and July 1, 3 young. Five nests were found at "Sand Creek Camp", June 17, 5 eggs; June 19, 6 eggs; June 20,3 eggs; and June 24,5 and 3 eggs.

Snow Bunting (Plectrophenax nivalis) 1: At Sachs Harbour a nest was found on a muddy bank under some dirt in which four eggs were laid, one daily, June 28 to July 1, all prior to 8:00 a.m. These egg's averaged $21.4 \times 15.4 \mathrm{~mm}$ in measurements. Longspur eggs were much darker but similar in size, with average measurements of 42 eggs, $21.53 \times 15.54 \mathrm{~mm}$ and average weight, $2.45 \mathrm{~g}$.

Other Information

A Tree Swallow (Iridoprocne bicolor) was found dead at Sachs Harbour, June 15 (spec. Nat. Museum of Canada). 
Plants collected June 14 at Sachs Harbour were: Cassiope tetragona, Stellaria laeta, Papaver radicatum, Arenaria rubella, Dryas integrifolia, Oxytropis arctica, Salix arctica, Agropyron latiglume, Trisetum spicatum, Poa alpigeua and Poa glauca.

In addition to these, I collected the following at Fish Lakes: Juncus biglumis, Carex membranacea, Salix richardsonii, Pedicularis lanata, Luzula confusa, Eriophorum callibrix, and Festuca callibrix. While at "Sand Creek" a few additional ones were added, Salix pseudopolaris and Kobresia bellardi. (Identifications were made by Dr. A. E. Porsild.)

A number of insects and spiders were identified by J. E. H. Martin, M. R. MacKay, H. E. Milliron, J. R. Vockeroth, J. G. Chillcott and W. J. Brown. The insects and spiders were: Araneida sp., Bombus sylvicola, Scatophaga multisetosa, Phalacrodira sp., Rymosia sp., Fucellia pictipennis, Hylemya sp., and Amara glacialis.

\section{Acknowledgments}

I wish to thank the above men who helped identify the plants and insects and spiders. I also wish to thank W. Earl Godfrey, National Museum of Canada, for all the help he gave me, as well as the Royal Canadian Mounted Police Officers, James Quinn and John Naeve at Sachs Harbour, and the men at the Federal Department of Transport headquarters for allowing me to use their headquarters facilities when I was in Sachs Harbour. I wish also to thank the Kuptana family, Robert, William and Roger, for transporting me by dog team from place to place.

\section{LITERATURE CITED}

Baker, B. W., and L. H. Walkinshaw. 1946. Bird notes from Fawcett, Aiberta. Can. Field-Nat., $60: 5-10$.

Manning, T. H., E. O. Höhn, and A. H. MacPherson. 1956. The birds of Banks Island. Nat. Mus. Canada, Bull. No. 143. Min. of N. Affairs and Nat. Resources, Ottawa. iv. + $144 \mathrm{p}$.

\title{
BLACK-HEADED GROSBEAK BREEDING RECORD FOR SOUTH-CENTRAL SASKATCHEWAN
}

\author{
by Robert D. Symons, Silton, and Robert W. Nero, Regina
}

The Black-headed Grosbeak (Pheucticus melanoleucus) has been known to breed in Canada in southern British Columbia, southern Alberta, and southern Saskatchewan (A.O.U., 1957). Salt and Wilk (1958) list it as a scarce summer resident for extreme southeastern Alberta. Godfrey (1950) reports it breeding in the Cypress Hills region of Saskatchewan, but it has not been known to nest elsewhere in this province. Observations which indicate a breeding record for south-central Saskatchewan on Last Mountain Lake, approximately 30 miles northwest of Regina, are therefore of considerable interest.

Symons observed and kept notes on a pair of Black-headed Grosbeaks at Pelican Point, Last Mountain Lake, from May 13 to October 13, 1962. Although a nest was not found, the adults were seen in the same vicinity during each month of this period, and fledged young were seen on July 27.

Symons recently prepared the following account of his observations, based on notes recorded at the time:

May 13: I first observed a pair of Black-headed Grosbeaks perched at a low level in a group of cultivated Russian poplars on a cottage lot. The trees were not yet in leaf. The early morning sun was not yet high, so the birds were not in shade on their undersides. This, combined with the colourless landscape of the pre-leafage period, made the birds appear as strongly and brilliantly coloured as orioles, for which indeed I at first mistook them. However, they lacked the dash and restlessness of orioles, and besides, their outline appeared more chunky. I approached to within 30 yards and recognized them as Black-headed Grosbeaks, having observed a male of 